Review

\title{
The Chemistry and Biology of Cyclophostin, the Cyclipostins and Related Compounds
}

\author{
Christopher D. Spilling
}

Department of Chemistry \& Biochemistry, University of Missouri-St. Louis, One University Boulevard, St. Louis, MO 63121, USA; cspill@umsl.edu

Academic Editor: Pawel Kafarski

Received: 22 May 2019; Accepted: 10 July 2019; Published: 16 July 2019

check for updates

Abstract: Cyclophostin, the cyclipostins and the salinipostins are structurally related cyclic enolphosphate natural products. This mini review describes their isolation, synthesis and biological activities. In addition, the synthesis and biological activities of monocyclic enolphosphate and mono and bicyclic enolphosphonate analogs are presented.

Keywords: cyclophostin; cyclipostins; enolphosphate; enolphosphonate; bicyclic; monocyclic; lipase; inhibitor

\section{Introduction}

Medicinal chemists have often turned to nature as a source of bioactive compounds, particularly for anticancer or antimicrobial agents [1-3]. Indeed, in a recent review it was reported that of the drugs approved between 1981 and 2010, 34\% were based on natural products, either directly or as derivatives [3]. The phosphate moiety is ubiquitous throughout nature and therefore phosphate containing natural products should provide additional opportunities for drug discovery. It is therefore not surprising that over the past 30 over years some very interesting, structurally related, biologically active bicyclic enolphosphates have been isolated from various Streptomyces strains. Their isolation, synthesis and biological activities, and the synthesis and biological activities of monocyclic enolphosphate and mono and bicyclic enolphosphonate analogs are discussed below.

\section{Discussion}

\subsection{Isolation and Structure of Cyclophostin}

In 1987, Neumann and Peter reported the isolation of two organophosphates during a search for natural insecticides [4]. The compounds CGA 134,736 (1a) and CGA 134,735 (1b) (Figure 1) were isolated from a soil organism Streptomyces antibioticus DMS 1951. The structures were assigned by X-ray crystallography and synthesis, although no spectroscopic or structural details were provided and no follow-up publications have appeared. Both compounds were reported to be good inhibitors of acetyl cholinesterase (AChE) with $\mathrm{IC}_{50}$ of between 0.7 and $5.7 \times 10^{-7} \mathrm{M}$.

Six years later, cyclophostin (2a) (Figure 1) was isolated from Streptomyces lavendulae (strain NK 901093) [5]. The structure was assigned using spectroscopic data and the absolute stereochemistry by X-ray crystallography with complete details of both reported in the manuscript. Cyclophostin is characterized by a unique cyclic phosphate triester fused to a lactone ring. The bicyclic core also contains an unusual vinylogous phosphate carbonic anhydride and has chiral centers at both phosphorus and the C-8a carbon atom $(3 R, 8 \mathrm{a} R)$ (see Section 2.4 below) with the methoxy and ring junction hydrogen in a cis relationship. Cyclophostin is a potent inhibitor of $\mathrm{AChE}$ with $\mathrm{IC}_{50}$ of $7.6 \times 10^{-10} \mathrm{M}$ for the enzyme from housefly and $1.3 \times 10^{-9} \mathrm{M}$ for the enzyme from brown plant hopper. 
<smiles>[R]C1=C2COC[C@H]2COP(=O)(OC)O1</smiles>

1a, $R^{2}=\operatorname{Me}(\mathrm{CGA} 134,736)$

1b, $\mathrm{R}^{2}=\mathrm{nC}_{3} \mathrm{H}_{7}(\mathrm{CGA} 134,735)$<smiles>COP1(=O)OC(C)=C2C(=O)OC[C@@H]2O1</smiles>

2a, cyclophostin

Figure 1. CGA 134,736, CGA 134,735 and cyclophostin.

\subsection{Isolation of the Cyclipostins}

In 2002, a family of structurally related natural products named the cyclipostins $(\mathbf{3 a} \mathbf{a} \mathbf{j})$ was reported (Figure 2). The cyclipostins were isolated from fermentation broths of Streptomyces sp. DSM 13381 [6-8]. Members of the cyclipostins family contain the same bicyclic core seen in cyclophostin, but vary in the nature of the lipophilic chain attached to the phosphate ester. The structures were assigned from spectroscopic data. Similar to cyclophostin, the cyclipostins possess the $3 R, 8 \mathrm{a} R$ relative stereochemistry, but no information on absolute configuration was given.<smiles>[R]C1=C2C(=O)OC[C@@H]2[CH]O[R]([R20])([H])O1</smiles>

3

3a, $R^{2}=M e, R^{1}=$ Cyclipostin A

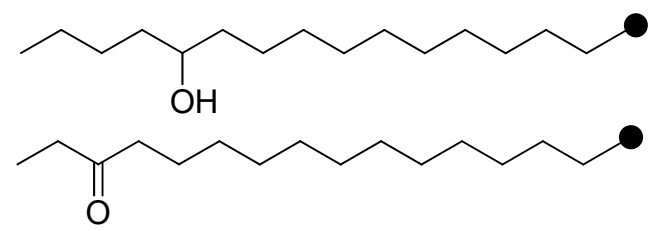

3c, $R^{2}=M e, R^{1}=$ Cyclipostin N

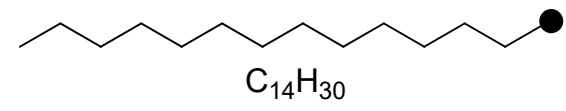

3d, $R^{2}=M e, R^{1}=$ Cyclipostin $P$<smiles>CCCCCCCCCCCCCCC</smiles>

3e, $R^{2}=M e, R^{1}=$

Cyclipostin P2

3f, $R^{2}=$ Me, $R^{1}=$ Cyclipostin $\mathrm{R}$<smiles>CCCCCCCCCCCCCCC(C)C</smiles>

$3 g, R^{2}=M e, R^{1}=$

Cyclipostin R2

3h, $R^{2}=E t, R^{1}=$ Cyclipostin $S$

3i, $R^{2}=\operatorname{Pr}, R^{1}=$ Cyclipostin $\mathrm{T}$

3j, $R^{2}=\operatorname{Pr}, R^{1}=$ Cyclipostin T2
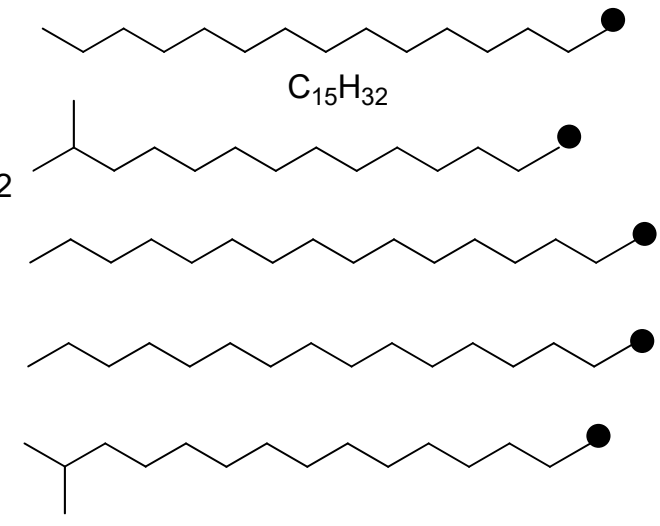

Figure 2. The cyclipostins. 
Many members of the cyclipostin family possess strong inhibitory activity against hormonesensitive lipase (HSL) with $\mathrm{IC}_{50}$ values in the nanomolar range. Furthermore, the lipophilic cyclipostins were also shown to block lipolysis in intact rat adipocytes by direct inhibition of hormone-sensitive lipase (HSL) [7]. A comparison of cell-free and whole-cell activity showed that the cyclipostins are efficiently transported into the cell. Further studies also showed that cyclipostins possess anti-mycobacterial activity [9]. Although the mechanism of the anti-mycobacterial was not directly discussed, the patent referred to enzymes related to hormone sensitive lipase produced by mycobacterium tuberculosis.

\subsection{Isolation of the Salinipostins}

In 2015, the Salinipostins (4) (Figure 3) were isolated from a marine sediment organism [10]. They are structurally similar to the cyclipostins, but with the alkoxy (ester) and ring junction hydrogen in a trans relationship or $(3 R, 8 \mathrm{a} S)$ (see Section 2.4). The structures were assigned based on spectroscopic data and comparison with compounds in the literature. Salinipostin A is a potent growth inhibitor of Plasmodium Falciparum $\left(\mathrm{EC}_{50}=50 \mathrm{nM}\right)$, the causative agent of malaria.

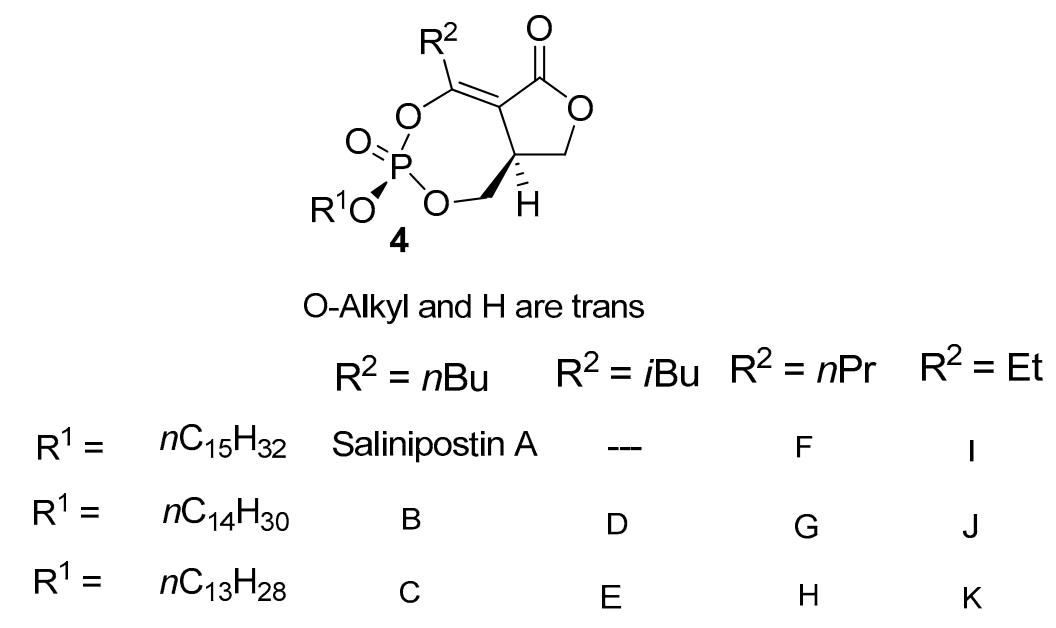

Figure 3. The salinipostins.

\subsection{Stereochemical Nomenclature}

In most cases, the structural determination for cyclophostin, the cyclipostins, and the salinipostins were made on the basis of spectroscopic data. However, determination of the structure of cyclophostin was also confirmed by X-ray crystallography. As pointed out by Spilling et al. in the first paper describing the synthesis of $( \pm)$ cyclophostin and $( \pm)$ cyclipostin P [11], the configuration named for cyclophostin in the isolation paper $(3 R, 8 \mathrm{a} S)$ is incorrect. A common error is to treat $\mathrm{P}^{+}-\mathrm{O}^{-}$as $\mathrm{P}=\mathrm{O}$ and hence assign the group priority incorrectly [12]. Natural cyclophostin is actually $3 R, 8 \mathrm{a} R$. \{CA index name $1 \mathrm{H}, 6 \mathrm{H}$-Furo[3,4-e][1,2,3]dioxphosphepin-6-one, 8,8a-dihydro-3-methoxy-5-methyl-, 3 -oxide $(3 R, 8 \mathrm{a} R)\}$. The authors of the salinipostin isolation paper made the same error in naming the stereochemistry as $S_{P}, S_{C}(3 S, 8 \mathrm{a} S)$, whereas it is in fact $R_{P}, S_{C}(3 R, 8 \mathrm{a} S)$. In both cases, the configurations are correctly named in chemical abstracts.

\subsection{Biosynthesis}

Cyclophostin, the cyclipostins, and the salinipostins are structurally related bicyclic enolphosphates. Indeed, Salinipostin F has the same enolphosphate alkyl substituent $(\mathrm{nPr})$ and phosphate ester of only one methylene unit less $\left(\mathrm{C}_{15}\right)$ than cyclipostin $\mathrm{T}\left(\mathrm{C}_{16}\right)$, albeit as the opposite diastereoisomer. In addition, there appears to be a structural relationship of cyclophostin, the cyclipostins and the salinipostins to other natural products isolated from Streptomyces species, e.g., the virginiae butanolides and A-factor (Figure 4), suggesting that there may be a common biosynthetic origin [13-18]. 
<smiles>[R]C(=O)C1C(=O)OC[C@@H]1CO</smiles><smiles>CC(C)CCCCC(=O)C1C(=O)OC[C@H]1CO</smiles>

A-factor<smiles>[R]C(O)C1C(=O)OC[C@H]1[CH]O</smiles>

virginiae butanolides<smiles>[R]=CCCCC(C)CCCCC</smiles>

Figure 4. A-factor and virginiae butanolides.

\subsection{Synthesis of ( \pm ) Cyclophostin and ( \pm ) Cyclipostin $P$}

The synthesis of racemic cyclophostin (2a) and cyclipostin P (3d) was reported in 2011 [11]. The hydroxyl moiety of lactone (5), which is available as a racemic mixture or as either enantiomer, was protected as a $p$-methoxybenzyl (PMB) ether (6) using the copper (II) triflate-catalyzed reaction of $p$-methoxybenzyloxy trichloroacetimidate (Scheme 1).
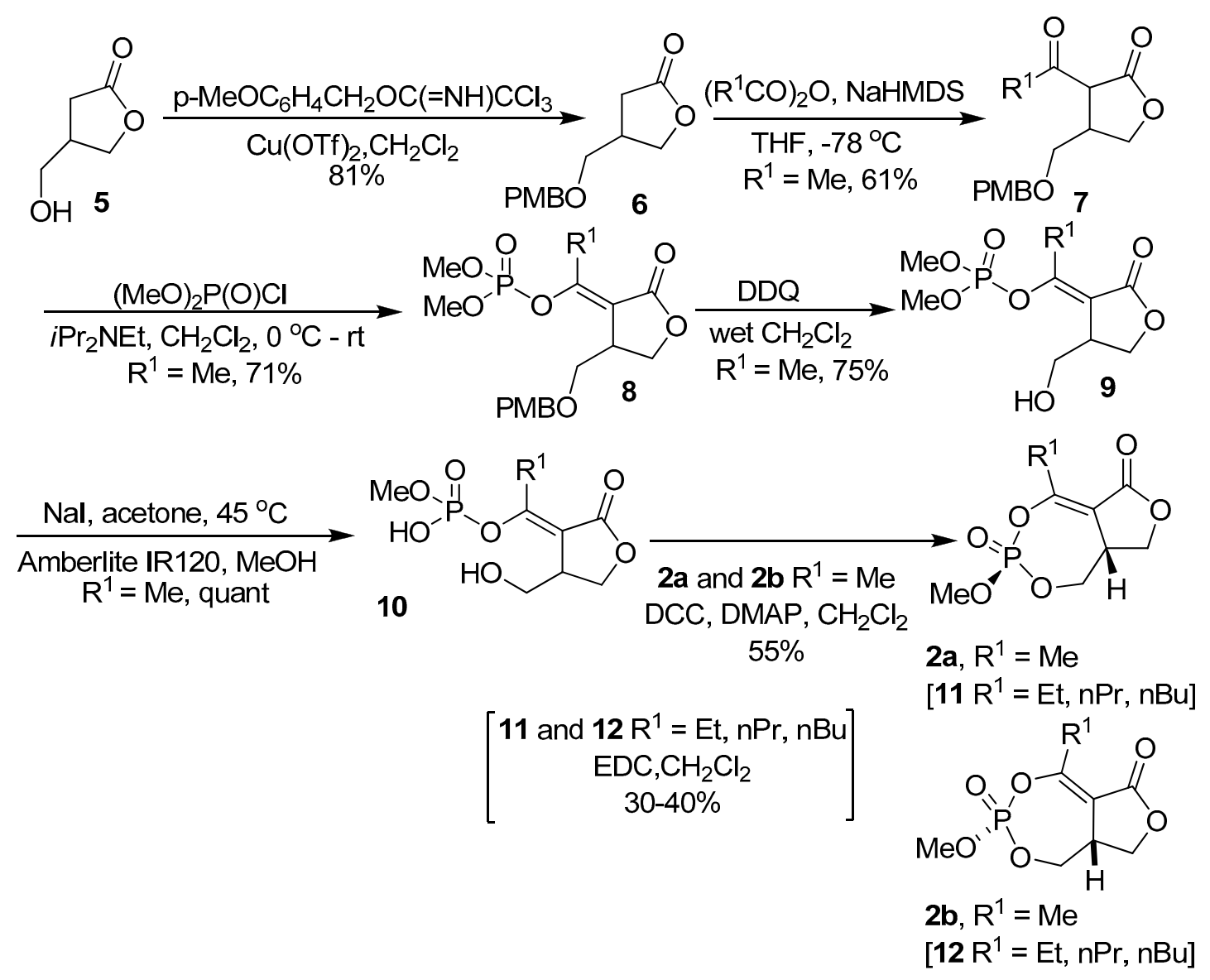

Scheme 1. The synthesis of $( \pm)$ cyclophostin and salinipostin analogs.

The acetyl group was installed by deprotonation of the lactone with NaHMDS and acylation with acetic anhydride. Selective phosphorylation of the resulting 2-acetyl butyrolactone (7) to form the E-enol phosphate (8) was achieved by reaction with dimethyl chlorophosphate using an organic base. 
The PMB-ether was removed using DDQ in wet $\mathrm{CH}_{2} \mathrm{Cl}_{2}$ and the enolphosphate (9) was selectively mono-demethylated using one equivalent of sodium iodide in acetone at $45^{\circ} \mathrm{C}$. The sodium salt was protonated with Amberlite IR $120^{\circledR}$ resin to generate the corresponding phosphoric acid (10). The phosphoric acid (10) was successfully cyclized with DCC and DMAP in $\mathrm{CH}_{2} \mathrm{Cl}_{2}$ to give the cyclic enolphosphates (2a) and (2b) as a 1:1 mixture. The diastereoisomers were separated using silica gel chromatography to give natural $( \pm$ ) cyclophostin (2a) and its diastereoisomer (2b) in $55 \%$ combined yield.

Cyclophostin (2a) and its diastereoisomer (2b) were converted to the cyclipostins by a novel one pot ester exchange process (Scheme 2). For example, the unnatural diastereoisomer $\mathbf{2} \mathbf{b}$ was treated with hexadecyl bromide (10 equivalents) and catalytic tetrabutylammonium iodide (TBAI) in refluxing dioxane to give cyclipostin P (3d) and its diastereoisomer (13) in a 1:1 ratio with $95 \%$ conversion. The diastereoisomers were separated by column chromatography to give a $77 \%$ combined yield. The reaction of either $(\mathbf{2} \mathbf{a})$ or $(\mathbf{2} \mathbf{b})$ with hexadecyl bromide and catalytic TBAI in refluxing dioxane resulted in a similar 1:1 mixture of (3d) and (13).<smiles>[R1]C1=C2C(=O)OC[C@H]2COP(=O)(OC)O1</smiles>

$$
\begin{aligned}
2 \mathrm{a}, \mathrm{R}^{1} & =\mathrm{Me} \\
{\left[11 \mathrm{R}^{1}\right.} & =\mathrm{Et}, \mathrm{nPr}, \mathrm{nBu}]
\end{aligned}
$$

or<smiles>[R]C1=C2C(=O)OC[C@H]2COP(=O)(OC)OC1</smiles>

2b, $\mathrm{R}^{1}=\mathrm{Me}$

$\left[12 \mathrm{R}^{1}=\mathrm{Et}, \mathrm{nPr}, \mathrm{nBu}\right]$
$\mathrm{Bu}_{4} \mathrm{NI}, 1,4-$ dioxane, reflux $\mathrm{R}^{2} \mathrm{Br}$ $\mathrm{R}^{1}=\mathrm{Me}, \mathrm{R}^{2}=\mathrm{nC}_{16} \mathrm{H}_{33} 77 \%$

$$
\begin{aligned}
& 4 \text { and 14, 60-70\% } \\
& \mathrm{R}^{1}=\mathrm{Et}, \mathrm{R}^{2}=\mathrm{nC}_{15} \mathrm{H}_{31} \\
& \mathrm{R}^{1}=\mathrm{nPr}, \mathrm{R}^{2}=\mathrm{nC}_{15} \mathrm{H}_{31} \\
& \mathrm{R}^{1}=\mathrm{nBu}, \mathrm{R}^{2}=\mathrm{nC}_{15} \mathrm{H}_{31} \\
& \mathrm{R}^{1}=\mathrm{Et}, \mathrm{R}^{2}=\mathrm{nC}_{14} \mathrm{H}_{29} \\
& \mathrm{R}^{1}=\mathrm{nPr}, \mathrm{R}^{2}=\mathrm{nC}_{14} \mathrm{H}_{29} \\
& \mathrm{R}^{1}=\mathrm{nBu}, \mathrm{R}^{2}=\mathrm{nC}_{14} \mathrm{H}_{29}
\end{aligned}
$$<smiles>[R]C1=C2C(=O)OC[C@H]2COP([R20])(=O)O1</smiles>

$3 d, R^{1}=M e$

[14]<smiles>[R]C1=C2C(=O)OC[C@H]2COP([R20])(=O)OC1</smiles>

13, $\mathrm{R}^{1}=\mathrm{Me}$

[4]

Scheme 2. The synthesis of $( \pm)$ cyclipostin P and the salinipostins.

\subsection{Synthesis of the Salinipostins}

Tao and coworkers reported the synthesis of six racemic salinipostins (4) and their diastereoisomers (14) (Schemes 1 and 2) [19]. They adopted the chemistry developed by Spilling et al. [11] for the synthesis of cyclophostin and the cyclipostins, substituting various carboxylic anhydrides for acetic anhydride to introduce the enol phosphate alkyl substituents $\left(R^{1}\right)$ required for the salinipostins. These researchers used EDC for the cyclization of the phosphoric acids.

\subsection{Synthesis of Mono and Bicyclic Phosphonate Analogs}

Spilling et al. reported the synthesis of phosphonate analogs of cyclophostin and the cyclipostins [20] and later adopted the chemistry to the preparation of several monocyclic phosphonate analogs [21-24]. The key C-C bond forming reaction involved a palladium-catalyzed substitution reaction of phosphono allylic carbonates (Scheme 3). The palladium-catalyzed reaction of methyl acetoacetate with the phosphono allylic carbonates (15) gave the vinyl phosphonates (16) in good yield. Selective hydrogenation of the vinyl phosphonate (16) using hydrogen over $10 \% \mathrm{Pd} / \mathrm{C}$ poisoned with pyridine gave the saturated phosphonates (17), which after selective demethylation, protonation of 
the resulting salt, and cyclization gave the monocyclic enolphosphonates (18). For the phosphonates, a combination of EDC and HOBt were the preferred reagents for cyclization. The cis and trans stereochemistry (OMe to $\mathrm{C} 5-\mathrm{H})$ was assigned initially by X-ray crystallography on (18h) and then a comparison of the ${ }^{31} \mathrm{P}$ NMR signals [22].

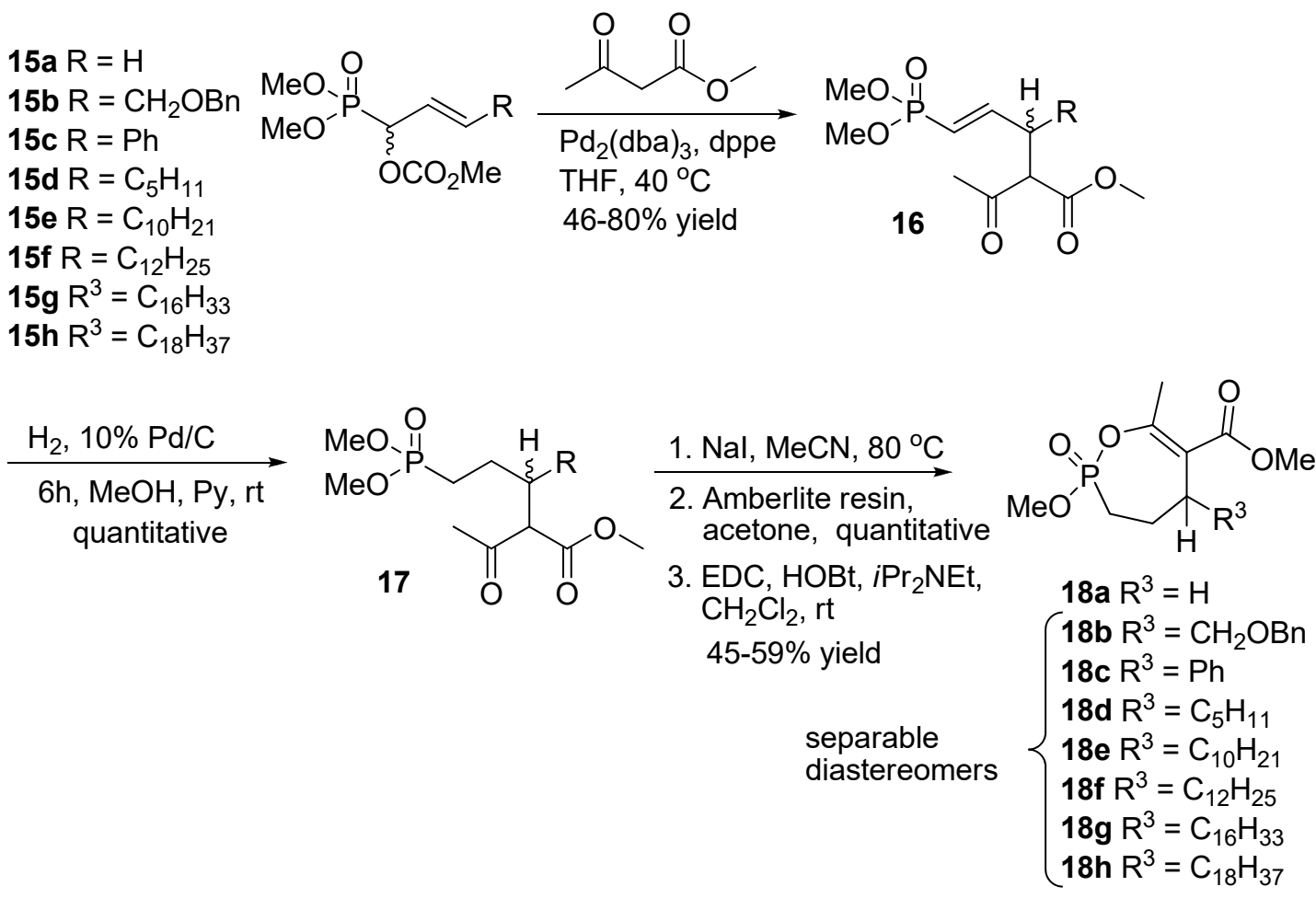

Scheme 3. The synthesis of mono cyclic enolphosphonates.

The phosphono allylic carbonates (15) can be prepared enantiomerically enriched and the palladium-catalyzed reaction of methyl acetoacetate proceeds with high transfer of the stereochemical information from the $\alpha$ position in the carbonate (15) to the $\gamma$ position of the vinyl phosphonate (16). This allowed the preparation of both enantiomers of both diastereoisomers of (18e) with enantiomeric excess (e.e.) of $>85 \%$ [23].

The bicyclic phosphonate analog of cyclophostin was available by the debenzylation of phosphonate (18b). Debenzylation of (18b) with hydrogen over palladium on carbon (Scheme 4) resulted in rapid lactonization to give the phosphonate isostere of cyclophostin (19a) and its diastereoisomer (19b) [20].<smiles>COC(=O)C1=C(C)OP(=O)(OC)CC[C@H]1COc1ccccc1</smiles>

$18 b$

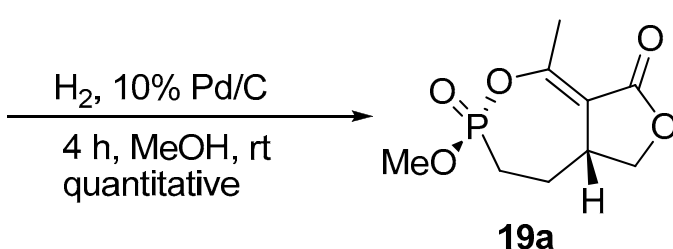

$19 a$

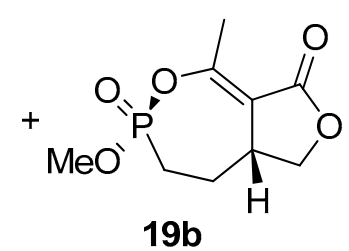

$19 b$

Scheme 4. The synthesis of phosphonate analogs of cyclophostin.

Conversion of the cyclophostin phosphonate analog (19a) to the diastereoisomeric cyclipostins analogs (20a and 20b) was achieved via in situ selective cleavage of the methyl phosphonate ester with tetrabutyl ammonium iodide (TBAI) and re-alkylation with a long chain alkyl bromide (Scheme 5). This reaction sequence was also successful with the monocyclic phosphonate analog (18a) giving long chain esters (21a and 21b) [24]. 
<smiles>COP1(=O)CC[C@H]2COC(=O)C2=C(C)OC1=O</smiles>

$19 b$<smiles>[R6][R]([R6])(O)CCC12COC(=O)C1=C(C)O2</smiles>

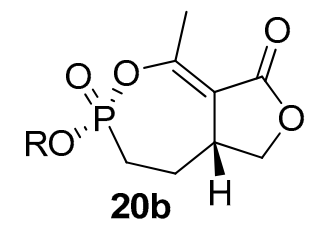

$\mathrm{R}=\mathrm{nC}_{16} \mathrm{H}_{33}(75 \%)$

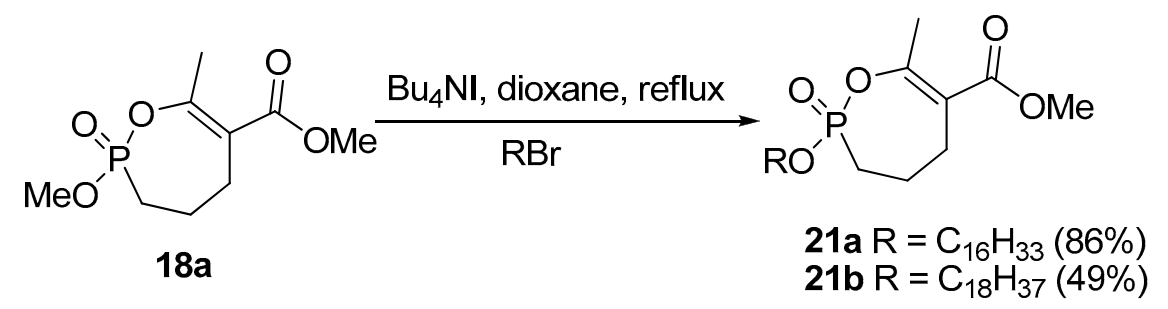

Scheme 5. The synthesis of mono and bicyclic analogs of the cyclipostins.

\subsection{Synthesis of Monocyclic Phosphate Analogs}

Spilling et al. expanded the structural variation in monocyclic analogs of cyclophostin and the cyclipostins with the synthesis of monocyclic phosphates and $\alpha, \alpha$-difluoro phosphonates [25]. To prepare the phosphate, $t$-butyl acetoacetate was alkylated with iodide (22) to give $\beta$-ketoester (23) (Scheme 6). An important feature of this synthesis is the selection of the tert-butyl ester, which minimizes the risk of lactonization upon deprotection of the PMB to reveal the alcohol. Reaction of the $\beta$-ketoester (23) with dimethyl chlorophosphite, followed by oxidation of crude material with $\mathrm{I}_{2}$ and methanol gave enolphosphate (24). The PMB ether protecting group was removed with DDQ to give alcohol (25). Demethylation and cyclization using 1-mesitylene-sulfonyl-3-nitrotriazole (MSNT) gave monocyclic tert-butyl ester (26). Cleavage of the tert-butyl moiety with TFA in anhydrous conditions was surprisingly effective and is a testament to the stability of the enolphosphate bond. The resulting carboxylic acid was treated with $\mathrm{TMSCHN}_{2}$ to give cyclic phosphate methyl ester cyclophostin analog (27). Trans-esterification gave the hexadecyl ester cyclipostin P analog (28).
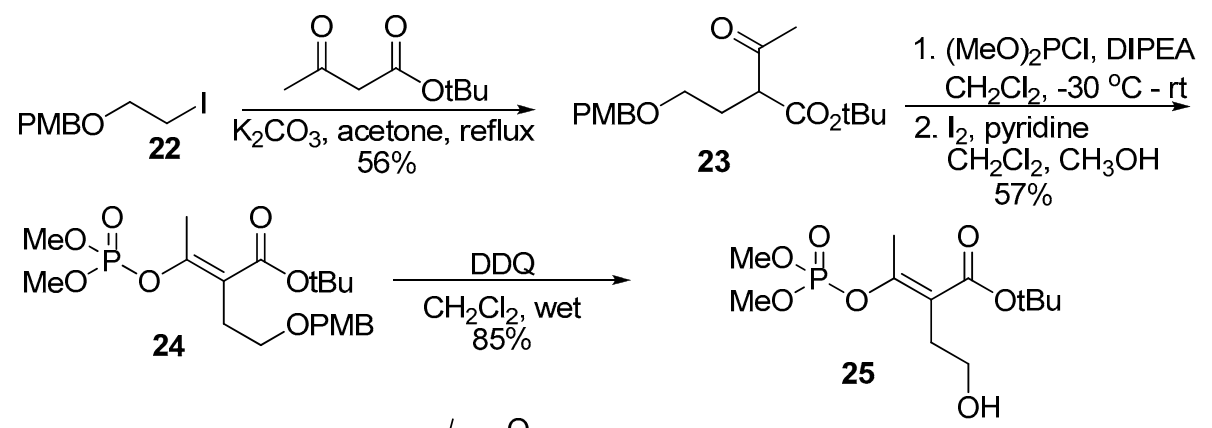

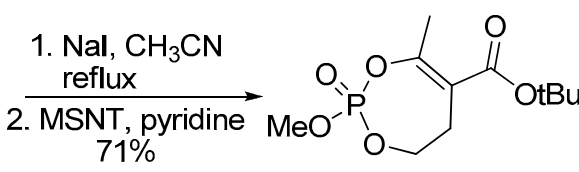

26

\section{TFA: $\mathrm{CH}_{2} \mathrm{Cl}_{2}(1: 3)$ \\ 2. $\mathrm{TMSCHN}_{2}, \mathrm{CH}_{2} \mathrm{Cl}_{2}$ $\mathrm{CH}_{3} \mathrm{OH}$} $74 \%$

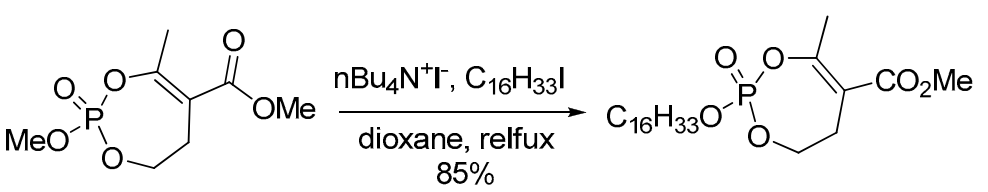

27
28

Scheme 6. The synthesis of the mono cyclic phosphates. 


\subsection{Synthesis of $\alpha, \alpha$-difluoro Phosphonate Analogs}

The (allyl-difluoro) phosphonate (30) was prepared by reaction of the cuprate of diethyl (bromodifluoromethyl) phosphonate (29) with allyl bromide (Scheme 7). Cross metathesis with methyl acrylate using Hoveyda-Grubbs II catalyst gave unsaturated ester (31), which was hydrogenated to the saturated ester (32). Formation of an enolate, trapping with acetic anhydride and hydrolysis of the crude product gave the $\beta$-ketoester (33). Selective de-ethylation was accomplished by treatment with NaI in refluxing acetonitrile. Cyclization with MSNT, produced cyclic $\alpha, \alpha$-difluorophosphonate cyclophostin analog (34). Trans-esterification using hexadecyl iodide gave the cyclipostin P analog (35). The difluoro enolphosphonates (34 and 35) were considerably less stable than the corresponding phosphonates and phosphates, resulting in lower yields after isolation by chromatography.<smiles>CCOP(=O)(OCC)C(F)(F)Br</smiles>

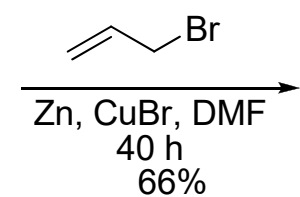<smiles>C=CCC(F)(F)P(=O)(OCC)OCC</smiles>

30

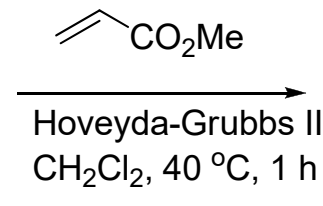

$71 \%$<smiles>CCOC(=O)P(=O)(OCC)C(F)(F)CCC(CCC(F)(F)P(=O)(OCC)OCC)C(C)=O</smiles>

33

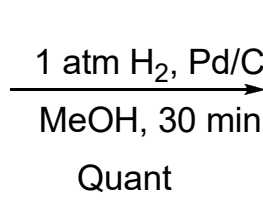

1. $\mathrm{Nal}, \mathrm{CH}_{3} \mathrm{CN}$ $80{ }^{\circ} \mathrm{C}, 3-5 \mathrm{~h}$

2. MSNT, Py, 1h $40 \%$<smiles>CCOP(=O)(OCC)C(F)(F)CCCC(C)=O</smiles><smiles>CCOP1(=O)OC(C)=C(C(C)=O)CCC1(F)F</smiles>

1. NaHMDS, $\mathrm{Ac}_{2} \mathrm{O}$ THF, $-78^{\circ} \mathrm{C}, 3 \mathrm{~h}$,

2. DMAP, $\mathrm{MeOH}$ $16 \mathrm{~h}$

$$
\begin{gathered}
\underset{27 \%}{\stackrel{\mathrm{nBu}_{4} \mathrm{~N}^{+} \mathrm{I}^{-}, \mathrm{C}_{16} \mathrm{H}_{33} \mathrm{l}}{\text { dioxane, relfux }}} \\
27 \%
\end{gathered}
$$

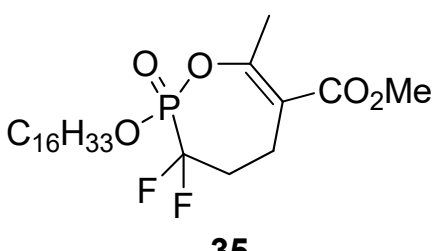

Scheme 7. The synthesis of the $\alpha, \alpha$-difluorophosphonates.

\subsection{Biological Activities}

Synthetic ( \pm ) cyclophostin (2a) inhibited human AChE with $\mathrm{IC}_{50}$ of $45 \mathrm{nM}[11,25]$. This compares well to the inhibition of AChE from two different insects by natural cyclophostin ( $\mathrm{IC}_{50}$ of 0.76 and $1.3 \mathrm{nM}$ ) [5], especially allowing for species difference. The diastereoisomer of cyclophostin (2b) was similarly active with $\mathrm{IC}_{50}$ of $40 \mathrm{nM}$. The bicyclic phosphonate analogs (19a and $\left.\mathbf{1 9 b}\right)$ were $10^{3}-10^{4}$ less active with $\mathrm{IC}_{50}$ of 30 and $3 \mu \mathrm{M}$, respectively $[20,21]$. The monocyclic phosphate $\left(\mathbf{2 7}, \mathrm{IC}_{50}=1 \mu \mathrm{M}\right)$ and monocyclic phosphonate $\left(\mathbf{1 8 a}, \mathrm{IC}_{50}=26 \mu \mathrm{M}\right)$ were also modest inhibitors [25]. The difluorophosphonate (35) was inactive and was also unstable in aqueous buffer, especially at $\mathrm{pH} 8.0$ [25].

Synthetic ( \pm ) cyclipostin P (3d) inhibited rat HSL with $\mathrm{IC}_{50}$ of $25 \mathrm{nM}$ [24], which again compares well with the reported data for natural cyclipostin $\mathrm{P}\left(\mathrm{IC}_{50} 30 \mathrm{nM}\right)$ [7]. The diastereoisomer of cyclipostin $\mathrm{P}(\mathbf{1 3})$ was 10 -fold less active with $\mathrm{IC}_{50}$ of $0.42 \mu \mathrm{M}$. The bicyclic phosphonate analogs (20a and 20b) were $10^{1}-10^{2}$ less active with $\mathrm{IC}_{50}$ of 6.9 and $0.36 \mu \mathrm{M}$, respectively [24]. The monocyclic phosphate $\left(28, \mathrm{IC}_{50}=60 \mathrm{nM}\right)$ and monocyclic phosphonate $\left(21 \mathrm{a}, \mathrm{IC}_{50}=0.54 \mu \mathrm{M}\right)$ were also good inhibitors of HSL. Again, the difluorophosphonate (35) was inactive and unstable [25]. The C5 alkyl substituted monocyclic phosphonates (18d-18h) proved to be weak inhibitors of HSL with $\mathrm{IC}_{50}$ in range of 10 to 
$>60 \mu \mathrm{M}$. Cyclophostin was inactive against HSL. It is interesting that the change from C16 alkyl to methyl phosphate switches selectivity from potent HSL inhibitor to potent AChE inhibitor, with little affinity for the other enzyme.

Although, the C5 alkyl substituted monocyclic phosphonates (18d-18h) were originally designed as inhibitors of HSL, they were shown to have good activity against microbial lipases [22,23]. Furthermore, compounds (3d), (18e and 18f) and (28) were shown to possess desirable activity against Mycobacterium tuberculous (M.tb., $\mathrm{MIC}_{50}=0.5-11.7 \mu \mathrm{M}$ ) and other mycobacteria [26,27]. Importantly, these inhibitors exhibited very low toxicity towards host macrophages $\left(\mathrm{CC}_{50}>100 \mu \mathrm{M}\right)$. Interestingly, data shows that the compounds exhibit two types of antibacterial activity. Some compounds have higher activity against intracellular than against extracellular bacteria. This suggests that there may be different modes of action with each set of compounds. Using activity-based protein profiling, 23 potential target enzymes of compound (28), which exhibited the best extracellular anti-tubercular activity, were identified [26-30]. Remarkably, all of the identified proteins were serine or cysteine enzymes; and most of them are involved in $M$. tb lipid metabolism or cell wall biosynthesis. Among them, the antigen 85 complex and TesA, playing key role in mycolic acid metabolism, have been further characterized as targets, and their respective crystal structures in complex with compounds (18f) and (28), respectively, have been solved [28,29].

Mass spectroscopic and X-ray crystallographic studies with several different enzymes [21,22,26-30] have shown that the enolphosphates (and phosphonates) function by phosphorylation of the active site serine (Figure 5). In some cases, the inactivated enzyme undergoes further chemistry by loss of the $\beta$-ketoester moiety [28].

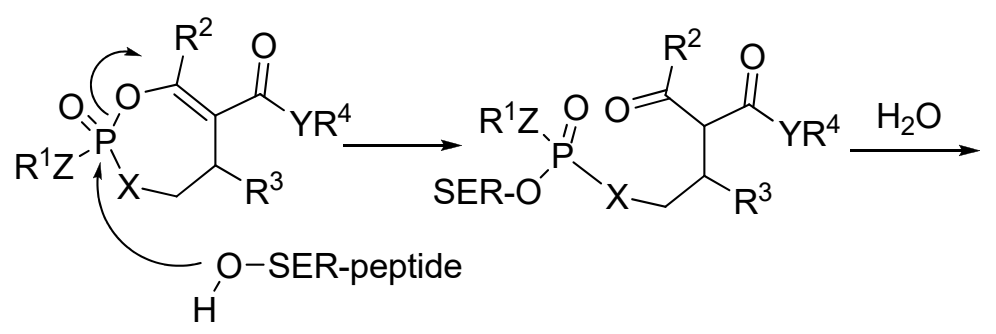<smiles>[R]C(=O)C(C([R])C([R])CO)C([R])C([R2])OP([R2])(O)=[Fe]</smiles>

Figure 5. The proposed mode of action for cyclic enolphosphates and phosphonates.

Given all of the data surrounding the cyclipostins and analogs, it is quite likely that the salinipostins act by inhibiting one or more serine hydrolase enzyme critical to plasmodium. The authors [10] suggest that the structure activity profile of the salinipostins resembles that of inhibitors of fatty acid synthase or enzymes responsible for the post translational modification of proteins (palmitoylation). Furthermore, attempts to produce P. Falciparum resistant to salinipostin A failed, suggesting these compounds target multiple enzymes as seen with M.tb.

\section{Conclusions}

Cyclophostin, the cyclipostins and the salinipostins represent an interesting class of biologically active phosphate containing natural products that have inspired the synthesis of several analogs.

There would appear to be enormous potential for cyclic enolphosphate and phosphonate analogs of cyclophostin (and the cyclipostins and salinipostins) to become a new general class of serine hydrolase inhibitor. Modifications can be easily introduced in $X, Y, Z, R^{1}, R^{2}, R^{3}$ and $R^{4}$ (Figure 6), to tailor specificity for a particular enzyme. Indeed, the strategies shown above already allow for the synthesis of a large variety of fully customizable monocyclic enolphosphonates. Furthermore, the methyl phosphonate and phosphates esters can be easily trans-esterified to give long chain ester compounds $\left(\mathrm{ZR}^{1}\right.$ chains, $\left.\mathrm{Z}=\mathrm{O}\right)$ analogous to the cyclipostins. 


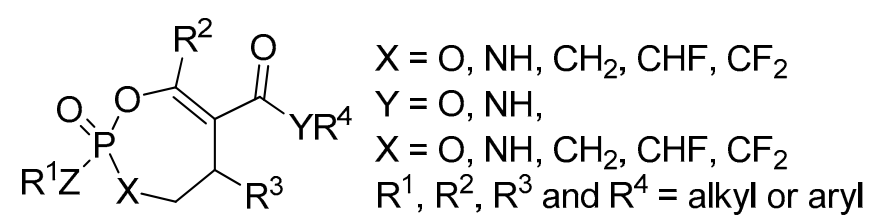

Figure 6. A general structure of enolphosphonates and enolphosphates.

Acknowledgments: I would like to thank Paul Hanson, University of Kanas for introducing me to cyclophostin and the cyclipostins, and also for informative discussions about phosphorus stereochemistry and nomenclature. I would also like to thank my collaborators in the area of cyclophostin and cyclipostin biology and biochemistry; Cynthia Dupureur, Department of Chemistry and Biochemistry, University of Missouri, USA and Jean-Francois Cavalier and Stephane Canaan, Aix-Marseille Univ, CNRS, LISM, Institut de Microbiologie de la Méditerranée, Marseille, France.

Conflicts of Interest: The authors declare no conflict of interest.

\section{References}

1. Harvey, A.L.; Edrada-Ebel, R.; Quinn, R.J. The Re-emergence of natural products for drug discovery in the genomic era. Nat. Rev. Drug Discov. 2015, 14, 111-129. [CrossRef] [PubMed]

2. Harvey, A.L. Natural products in drug discovery. Drug Discov. Today 2008, 13, 894-901. [CrossRef] [PubMed]

3. Newman, D.J.; Cragg, G.M. Natural products as sources of new drugs over the 30 years from 1981 to 2010. J. Nat Prod. 2012, 75, 311-335. [CrossRef] [PubMed]

4. Neumann, R.; Peter, H.H. Insecticidal organophosphates: Nature made them first. Experimentia 1987, 43, 1235-1237. [CrossRef]

5. Kurokawa, T.; Suzuki, K.; Hayaoka, T.; Nakagawa, T.; Izawa, T.; Kobayashi, M.; Harada, N. Cyclophostin, Acetylcholinesterase inhibitor from Streptomyces lavendulae. J. Antibiot. 1993, 46, 1315-1318. [CrossRef] [PubMed]

6. Wink, J.; Schmidt, F.-R.; Seibert, G.; Aretz, W. Cyclipostins: Novel hormone sensitive lipase inhibitors from Streptomyces sp. DSM 13381 I. Taxonomic studies of the producer microorganism and fermentation results. J. Antibiot. 2002, 55, 472-479. [CrossRef] [PubMed]

7. Vertesy, L.; Beck, B.; Brönstrup, M.; Ehrlich, K.; Kurz, M.; Müller, G.; Schummer, D.; Seibert, G. Cyclipostins: Novel hormone sensitive lipase inhibitors from Streptomyces sp. DSM 13381 II. Isolation, structure, elucidation and biological properties. J. Antibiot. 2002, 55, 480-494. [CrossRef]

8. Vertesy, L.; Ehrlich, K.; Kurz, M.; Wink, J. Cyclopostins, Process for their Preparation and Use Thereof. U. S. Patent US 6,756,402 B2, 29 June 2004.

9. Seibert, G.; Toti, L.; Wink, J. Treating Mycobacterial Infections with Cyclipostins. WO/2008/025449, 6 March 2008.

10. Schulze, C.J.; Navarro, G.; Ebert, D.; DeRisi, J.; Linnington, R.G. Salinipostins A-K, long-chain bicyclic phosphotriesters as a potent and selective antimalarial chemotype. J. Org. Chem. 2015, 80, 1312-1320. [CrossRef]

11. Malla, R.K.; Bandyopadhyay, S.; Spilling, C.D.; Dutta, S.; Dupureur, C.M. The first total synthesis of $( \pm)$ cyclophostin and $( \pm)$ cyclipostin P: Inhibitors of the serine hydrolases acetyl cholinesterase and hormone sensitive lipase. Org. Lett. 2011, 13, 3094-3097. [CrossRef]

12. Cahn, R.S.; Ingold, C.K.; Prelog, V. Specification of molecular chirality. Angew. Chem. Int. Ed. 1966, 5, 385-415. [CrossRef]

13. Morin, J.B.; Adams, K.L.; Sello, J.K. Replication of biosynthetic reactions enables efficient synthesis of A-Factor, a $\gamma$-butyrolactone autoinducer from Streptomyces griseus. Org. Biomol. Chem. 2012, 10, 1517-1520. [CrossRef] [PubMed]

14. Nihira, T.; Shimizu, Y.; Kim, H.S.; Yamada, Y. Structure-activity relationships of virginiae butanolide C, an inducer of virginiamycin production in Streptomyces virginiae. J. Antbiot. 1988, 1828-1837. [CrossRef]

15. Sakuda, S.; Higashi, A.; Tanaka, S.; Nihira, T.; Yamada, Y. Biosynthesis of virginiae butanolide A, a butyrolactone autoregulator from Streptomyces. J. Am. Chem. Soc. 1992, 114, 663-668. [CrossRef] 
16. Sakuda, S.; Tanaka, S.; Mizuno, K.; Sukcharoen, O.; Nihira, T.; Yamada, Y. Biosynthetic studies on virginiae butanolide A, a butyrolactone autoregulator from Streptomyces. Part 2. Preparation of Possible Biosynthetic intermediates and conversion experiments in cell-free system. J. Chem. Soc. Perkin Trans. I 1993, 2309-2315. [CrossRef]

17. Takano, E.; Nihira, T.; Hara, Y.; Jones, J.J.; Gershater, C.J.L.; Yamada, Y.; Bibb, M. Purification and structural determination of SCB1, a $\gamma$-butyrolactone that elicits antibiotic production in Streptomyces coelicolor A3(2). J. Biol. Chem. 2000, 275, 11010-11016. [CrossRef]

18. Kato, J.; Funa, N.; Watanabe, H.; Ohnishi, Y.; Horinouchi, S. Biosynthesis of $\gamma$-butyrolactone autoregulators that switch on secondary metabolism and morphological development in Streptomyces. Proc. Natl. Acad. Sci. USA 2007, 104, 2378-2383. [CrossRef] [PubMed]

19. Zhao, M.; Wei, X.; Liu, X.; Dong, X.; Yu, R.; Wan, S.; Jiang, T. Total synthesis of marine cyclic enol-phosphotriester salinipostin compounds. J. Ocean. Univ. China 2018, 17, 683-689. [CrossRef]

20. Bandyopadhyay, S.; Dutta, S.; Spilling, C.D.; Dupureur, C.M.; Rath, N.P. Synthesis and biological evaluation of a phosphonate analog of the natural acetyl cholinesterase inhibitor cyclophostin. J. Org. Chem. 2008, 73, 8386-8391. [CrossRef]

21. Dutta, S.; Malla, R.K.; Bandyopadhyay, S.; Spilling, C.D.; Dupureur, C.M. Synthesis and kinetic analysis of some phosphonate analogs of cyclophostin as inhibitors of human acetylcholinesterase. Bioorg. Med. Chem. 2010, 18, 2265-2274. [CrossRef]

22. Point, V.; Malla, R.K.; Diomande, S.; Martin, B.P.; Delorme, V.; Carrière, F.; Canaan, S.; Rath, N.P.; Spilling, C.D.; Cavalier, J.-F. Synthesis and kinetic evaluation of cyclophostin and cyclipostins phosphonate analogs as selective and potent inhibitors of microbial lipases. J. Med. Chem. 2012, 55, 10204-10219. [CrossRef]

23. Point, V.; Malla, R.K.; Carrière, F.; Canaan, S.; Spilling, C.D.; Cavalier, J.-F. Enantioselective inhibition of microbial lipolytic enzymes by nonracemic monocyclic enolphosphonate analogs of cyclophostin. J. Med. Chem. 2013, 56, 4393-4401. [CrossRef] [PubMed]

24. Vasilieva, E.; Dutta, S.; Malla, R.K.; Martin, B.P.; Spilling, C.D.; Dupureur, C.M. Rat hormone sensitive lipase inhibition by cyclipostins and their analogs. Bioorg. Med. Chem. 2015, 23, 944-952. [CrossRef]

25. Martin, B.P.; Vasilieva, E.; Dupureur, C.M.; Spilling, C.D. Synthesis and comparison of the biological activity of monocyclic phosphonate, difluorophosphonate and phosphate analogs of the natural AChE inhibitor cyclophostin. Bioorg. Med. Chem. 2015, 23, 7529-7534. [CrossRef] [PubMed]

26. Nguyen, P.C.; Delorme, V.; Bénarouche, A.; Martin, B.P.; Paudel, R.; Gnawali, G.R.; Madani, A.; Puppo, R.; Landry, V.; Kremer, L.; et al. Cyclipostins and cyclophostin analogs as promising compounds in the fight against tuberculosis. Sci. Rep. 2017, 7, 11751. [CrossRef] [PubMed]

27. Nguyen, P.C.; Madani, A.; Santucci, P.; Martin, B.P.; Paudel, R.; Delattre, S.; Herrmann, J.-L.; Spilling, C.D.; Kremer, L.; Canaan, S. Cyclophostin and cyclipostins analogs, new promising molecules to treat mycobacterial-related diseases. Int. J. Antimicrob Agents 2018, 51, 651-654. [CrossRef] [PubMed]

28. Viljoen, A.; Richard, M.; Nguyen, P.C.; Fourquet, P.; Camoin, L.; Paudal, R.; Gnawali, G.R.; Spilling, C.D.; Cavalier, J.-F.; Canaan, S.; et al. Cyclipostins and cyclophostin analogs inhibit the antigen 85C from Mycobacterium tuberculosis both in vitro and in vivo. J. Biol. Chem. 2018, 293, 2755-2769. [CrossRef]

29. Nguyen, P.C.; Nguyen, V.S.; Martin, B.P.; Fourquet, P.; Camoin, L.; Spilling, C.D.; Cavalier, J.-F.; Cambillau, C.; Canaan, S. Biochemical and structural characterization of TesA, a major thioesterase required for outer-envelope lipid biosynthesis in M. tuberculosis. J. Mol. Biol. 2018, 430, 5120-5136. [CrossRef]

30. Santucci, P.; Point, V.; Poncin, I.; Guy, A.; Crauste, C.; Serveau-Avesque, C.; Galano, J.M.; Spilling, C.D.; Cavalier, J.F.; Canaan, S. LipG a bifunctional phospholipase/thioesterase involved in mycobacterial envelope remodeling. Biosci. Rep. 2018, 38, BSR20181953. [CrossRef]

(C) 2019 by the author. Licensee MDPI, Basel, Switzerland. This article is an open access article distributed under the terms and conditions of the Creative Commons Attribution (CC BY) license (http://creativecommons.org/licenses/by/4.0/). 